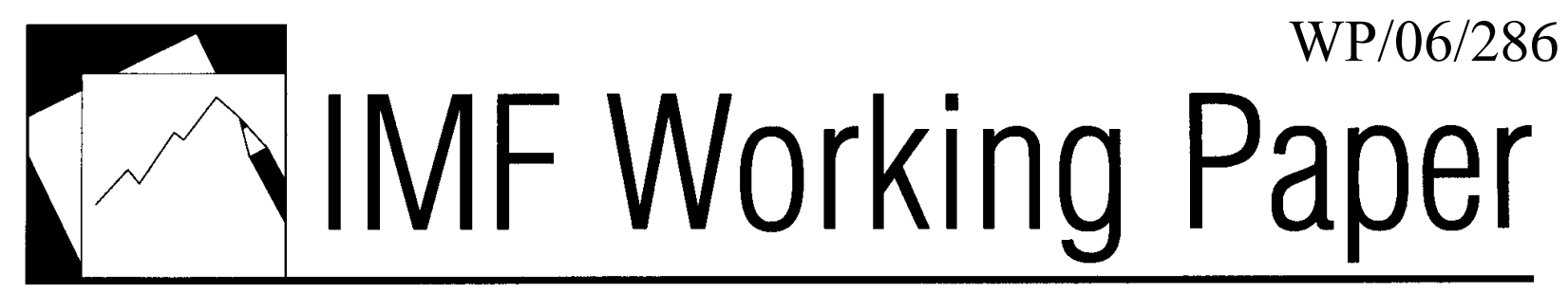

\title{
Managing and Controlling Extrabudgetary Funds
}

\author{
Richard Allen and Dimitar Radev
}





\title{
IMF Working Paper
}

Fiscal Affairs Department

\section{Managing and Controlling Extrabudgetary Funds}

\section{Prepared by Richard Allen and Dimitar Radev ${ }^{1}$}

Authorized for distribution by Thanos Catsambas

December 2006

\begin{abstract}
This Working Paper should not be reported as representing the views of the IMF. The views expressed in this Working Paper are those of the author(s) and do not necessarily represent those of the IMF or IMF policy. Working Papers describe research in progress by the author(s) and are published to elicit comments and to further debate.

This paper addresses issues relating to the establishment and financial management of extrabudgetary funds (EBFs), a large group of government entities that on average accounts for 40 to 45 percent of central government expenditure - two-thirds of which represents social security funds - in countries at various stages of development. If improperly designed and managed, EBFs can undermine effective fiscal control. However, they also bring potential benefits in the form of greater autonomy of decision-making in countries with well-established governance and financial management systems that have applied the "agency model" of devolved public management and fiscal control. The paper develops a typology of EBFs and argues that EBFs are frequently created because of failures in the budget system and political economy factors that need to be recognized and, where possible, corrected. The paper recommends that data on EBFs be consolidated within a unified system of fiscal reporting and proposes an analytical framework that governments might use to evaluate the effectiveness and utility of their EBFs.

JEL Classification Numbers: E62, H29, H59, and H61

Keywords: extrabudgetary fund, fiscal earmarking, agency model

Author's E-Mail Address: rallen2@imf.org; dradev@,imf.org

\footnotetext{
${ }^{1}$ The authors are grateful for helpful comments from Thanos Catsambas, James Daniel, Jeffrey Davis, Jim Brumby, Holger van Eden, Dale Hart, Mark Horton, Abdul Khan, Duncan Last, Ian Lienert, Rolando Ossowski, Barry Potter, Gerd Schwartz, Eivind Tandberg, Theo Thomas, and other IMF colleagues, mainly from the Fiscal Affairs Department; also from T.K. Balakrishnan, Bill Dorotinsky, and Salvatore Schiavo-Campo (World Bank), and Dirk-Jan Kraan (OECD).
} 


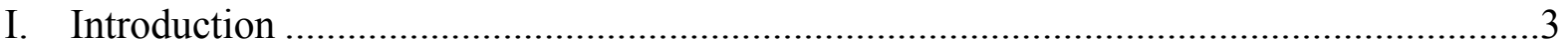

II. Definition, Data, Classification, and Typology of EBFs …....................................

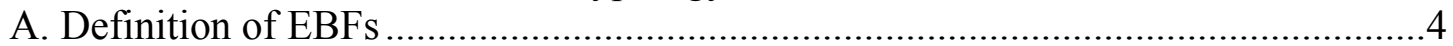

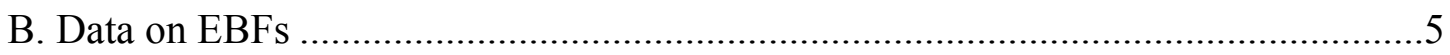

C. Classification and Typology of EBFs .........................................................

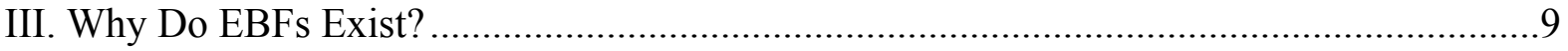

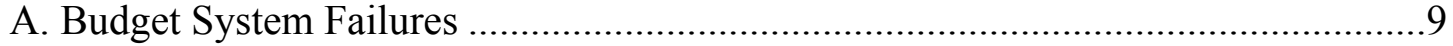

B. Political Economy Factors ................................................................................. 11

C. Benefit Principle of Taxation and Earmarking .................................................. 12

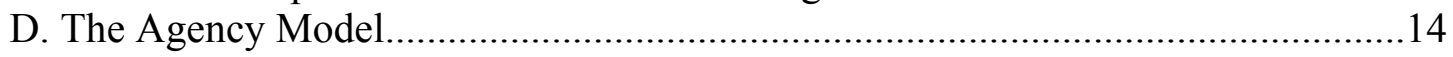

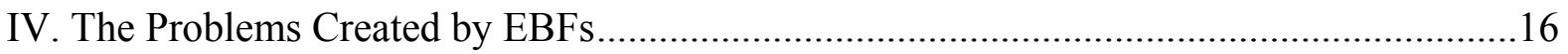

V. Criteria for Evaluating and Reforming EBFs ........................................................19

VI. Implications for the Analysis of Fiscal Policies and Public Financial Management ........23

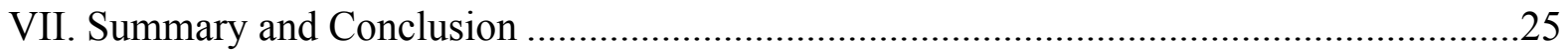

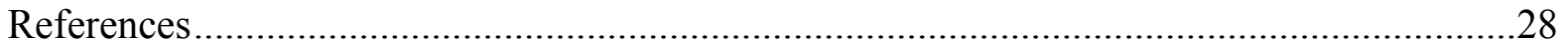

Tables

1. EBFs and Central Government Expenditures ..............................................................6

Boxes

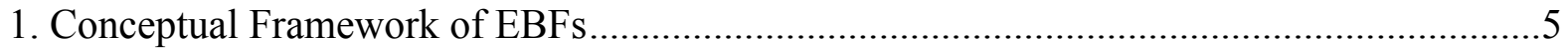

2. Benefit Principle of Taxation and Fiscal Earmarking................................................. 13

3. Definition of Public Agencies........................................................................................ 14

4. A Governance and Financial Regime for Nondepartmental Public Bodies .......................16

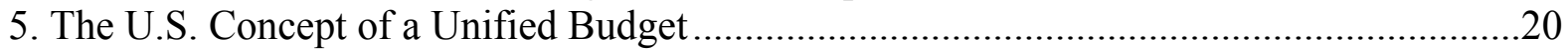

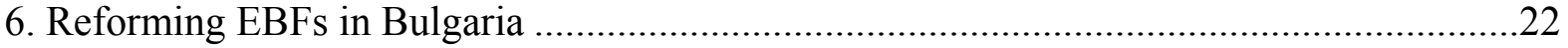




\section{INTRODUCTION}

The purpose of this paper is to develop a comprehensive framework for analyzing the establishment and financial management of EBFs, an important category of public expenditure that is, by definition, outside the parameters and control of conventional budgetary rules and procedures. ${ }^{2}$ The paper draws on the experience of EBFs in several countries; and on the findings of papers by International Monetary Fund (IMF) staff and other authors who have reviewed certain categories of EBFs, especially oil funds and road maintenance funds. ${ }^{3}$ It has been written with a general audience in view, but Section VI is of particular relevance to the IMF and development agencies that have surveillance or program activities in the countries concerned.

EBFs are important because:

- $\quad$ on average, they account for more than 40 percent of central government expenditure in both developed and developing countries;

- $\quad$ in some circumstances, they may have serious fiscal policy, public financial management, and governance implications; and

- $\quad$ to some commentators, EBFs represent an errant form of public sector activity that often has distortionary and harmful effects, in particular for overall macrofiscal stability and control.

Much of the analysis of EBFs carried out by IMF staff and other organizations has focused largely on their macrofiscal impact and how to deal with the resulting problems (e.g., by abolishing existing EBFs and legislating against the establishment of new ones). However, the concept of an EBF, and the policy implications, are more complex than often perceived. Extrabudgetary funds come in many forms. Some are financed through earmarked taxes wholly or partially, others out of general taxation. Certain EBFs, especially in Organization for Economic Cooperation and Development (OECD) countries, take the form of public agencies with highly developed governance and financial management arrangements, heavily regulated by the ministry of finance. Others are managed on an ad hoc basis with little regulation.

The present paper attempts to disentangle and analyze several issues related to EBFs that are interrelated and intermingled. It argues that a thorough investigation of EBFs requires a full understanding and analysis of the economic, governance, and political economy factors that are fundamental to their existence. Indeed, it is helpful to view EBFs as the consequence of

\footnotetext{
${ }^{2}$ For a traditional view of EBFs, see Allen and Tommasi (2001). The IMF's position toward EBFs evolved in the late 1990s by defining conditions under which EBFs might be acceptable. See Potter and Diamond (1999). The present paper does not review policy in relation to certain other categories of "off-budget expenditures" such as direct loans, government guarantees, and public-private partnerships that have certain characteristics in common with EBFs but require a separate analysis.

${ }^{3}$ See Davis and others (2001); Potter (1997).
} 
various "market" or budgetary failures, many arising from political economy factors, rather than simply as a macrofiscal problem.

Against this backdrop, the paper develops a broad analytical framework for the assessment of EBFs. In addition, it addresses the following questions:

- Is there a need for an evolution of the existing policy position on EBFs?

- How should the complex issues and arguments set out in this paper-which relate to economics, political economy, governance, and public management—be taken into account in developing the analytical framework?

- What criteria should countries use to evaluate whether their EBFs should continue to exist, be commercialized or privatized, or be abolished?

- What are the practical implications for macrofiscal policies and public financial management in developing and transition countries?

To address these questions, the paper looks at the definition, data, classification, and typology of EBFs; examines why EBFs exist; analyzes the problems created by EBFs, and criteria for evaluating and reforming them; and looks at the implications for analysis of fiscal policies and for public financial management.

\section{Definition, DATA, Classification, AND TyPology OF EBFs}

Although the term EBF seems self-explanatory, in practice it refers to a diverse and often complex set of issues. Introducing a meaningful definition and typology is helpful in clarifying the concept of EBFs and distinguishing their many different varieties.

\section{A. Definition of EBFs}

As shown in Box 1, the literature includes several definitions of an EBF.

The term "extrabudgetary" can be considered as an umbrella concept that may be used in several ways, each emphasizing a different aspect of the issue. Extrabudgetary transactions are the broadest concept and include all revenues, expenditures, and financing that are excluded from the budget. Extrabudgetary accounts are the bank arrangements into which extrabudgetary revenues and expenditures are paid in and disbursed. Extrabudgetary entities (or units) are institutions that are engaged in extrabudgetary transactions, may use extrabudgetary accounts, and may have their own governance structures and, often, a legal status that is independent of government ministries and departments.

In this paper, EBFs refer to general government transactions, often with separate banking and institutional arrangements, that are not included in the annual state (federal) budget law and the budgets of subnational levels of government. The paper especially focuses on 


\section{Box 1. Conceptual Framework of EBFs}

The IMF's Government Finance Statistics Manual published in 2001 (GFSM 2001) provides a comprehensive conceptual and accounting framework for analyzing and evaluating fiscal policies, especially the performance of the general government sector, which includes EBFs. The GFSM 2001 distinguishes EBFs from the government's "legislative budget" (namely, the budget that is enacted by law) because of their differing sources of finance and the various types of public oversight of their operations. ${ }^{1}$

According to the IMF's Manual on Fiscal Transparency various kinds of operations may be set up outside the annual appropriations process, and are thus referred to as extrabudgetary. The term EBFs generally refers to government transactions that are not included in the annual budget presentation. These may not be subject to the same level of scrutiny or accounting standards as the annual budget. ${ }^{2}$

According to the IMF's Guidelines on Public Expenditure Management, ${ }^{3}$ EBFs generally refer to government transactions that are not included in the budget totals or documents and typically are not subject to normal budgetary execution and control procedures. Such transactions may be financed by foreign aid or earmarked revenues that are not included in the budget.

Extrabudgetary Funds have also been defined as "special funds owned by the government that are not part of the budget and that receive revenues from earmarked levies, possibly next to other sources such as fees and contributions from the general tax fund."

The way in which the term "budget" is defined is also important. In some countries, the term is restricted to the estimates related to annual appropriations of funds by the legislature. This concept, however, may capture only a small proportion of total fiscal transactions.

The concept of the consolidated (unified) budget, promoted in the United States in the late 1960s, is becoming increasingly popular as an approach for organizing and presenting the budget in OECD countries. The consolidated federal budget includes both the general budget and certain extrabudgetary transactions.

1/ GFSM 2001, paragraph 2.45.

2/ Observance of Standards and Codes (2001), pp. 12 and 73.

3/ Potter and Diamond, op. cit., p. 25.

4/ Kraan (2004).

institutional arrangements of EBFs when they are organized as separate government entities. ${ }^{4}$ However, such entities may not capture all extrabudgetary transactions. It is thus important that fiscal surveillance classifies extrabudgetary activities according to GFSM 2001 principles, as discussed in sections IIC and VI, in order to provide a comprehensive analysis.

\section{B. Data on EBFs}

Table 1 summarizes data on EBFs provided in the 2005 edition of the IMF's Government Finance Statistics Yearbook.

\footnotetext{
${ }^{4}$ It is possible to create some degree of separation of funds within the budget process without reverting to an EBF. For example, all revenues and expenditures of the Norwegian State Petroleum Fund (SPF) flow through the budget, and the fund does not have an independent management board. Funds are held in a ministry of finance bank account in the central bank and all decisions regarding the fund are taken by the parliament in the annual budget process, or by the ministry. The cash management of the SPF has been outsourced to the central bank, working under very detailed policies, guidelines and direct supervision of the ministry of finance.
} 
Table 1. EBFs and Central Government Expenditures 1/

\begin{tabular}{lcccc}
\hline \multirow{2}{*}{ Group of Countries } & \multicolumn{2}{c}{ EBFs Outlays } & \multicolumn{2}{c}{ Social Security Fund Outlays } \\
\cline { 2 - 5 } & \% of total outlays & \% of GDP & \% of total outlays & \% of GDP \\
\hline & 14.3 & 4.4 & 35.6 & 12.5 \\
Developed countries 2/ & 13.2 & 2.8 & 26.2 & 5.4 \\
Transition/Developing countries 3/ & 13.4 & 3.1 & 30.2 & 8.4 \\
All countries & & & & \\
\hline
\end{tabular}

Sources: EBFs, social security, and total outlay data from the 2005 GFS Yearbook CD-ROM. GDP data come from the IMF World Economic Outlook (April 2006). Range of data: 2002-04 (most recent available data by country).

1/ Data from the GFS Yearbook are presented on a gross basis for all subsectors. Existing sectors correspond to those described in the institutional tables of the 2005 GFS Yearbook.

2/ Includes countries that are classified as high income according to the World Bank Atlas Method (Gross national income per capita of US $\$ 10,066$ or more). Sample of 8 countries for data on EBF outlays, 17 countries for data on social security outlays.

3/ Includes countries that are classified as low income, low middle income, and high middle income according to the World Bank Atlas Method. Sample of 25 countries for data on EBF outlays, 23 countries for data on social security outlays.

The following conclusions may be drawn from these data:

- $\quad$ EBFs represent a significant part of central government expenditures. Including social security funds, they account for about 44 percent of total expenditures. ${ }^{5}$

- Social security funds are the single most dominant form of extrabudgetary activities, accounting for more than 30 percent of total expenditures.

- While the level of extrabudgetary activities, excluding social security funds, is broadly comparable for both developed countries and transition and developing countries, social security funds represent a significantly bigger portion of central government expenditures in developed countries.

- $\quad$ More detailed analysis of the data suggests that EBFs in many developed countries have a well established institutional framework - mainly variations of the agency model discussed in Section III below, while transition and developing countries use a wider range of arrangements, sometimes without a clear economic and legal identity.

- $\quad$ EBFs in developed countries are generally well integrated with the budget processin line with the concept of the consolidated budget discussed later in this paper; and in some cases are not presented as a separate government subsector. For example, in line with the presentation adopted within the European Union (EU), data for EBFs for most EU member countries are presented as part of the central government budget.

\footnotetext{
${ }^{5}$ Budgetary accounts reflect the EBFs expenditures to the extent they are financed through transfers from the budget.
} 


\section{Classification and Typology of EBFs}

The proper classification of EBFs is important to ensure that fiscal data are comprehensive and fiscal targets are properly defined. Such a classification should start from the framework of concepts and definitions for statistical reporting set out in the GFSM 2001 and equivalent international standards. The GFSM 2001 puts the emphasis on the economic characteristics of an entity rather than its legal form. The basic concept is that of an "institutional unit," which is defined as "an economic entity that is capable, in its own right, of owning assets, incurring liabilities, and engaging in economic activities and in transactions with other entities." The institutional unit is also characterized by "a complete set of accounts, including a balance sheet of assets, liabilities, and net worth."

The GFSM 2001 guidelines seem to allow specifically for the inclusion of EBFs within its classification system. In particular:

"There may however be government entities with a separate legal identity and substantial autonomy, including discretion over the volume and composition of their expenditures and a direct source of revenue, such as earmarked taxes. Such entities are often established to carry out specific functions, such as road construction or the nonmarket production of health or education services. These entities should be treated as separate government units if they maintain full sets of accounts, own goods or assets in their own right, engage in nonmarket activities for which they are held accountable in law, and are able to incur liabilities and enter into contracts" (paragraph 2.24).

GFSM 2001 goes further in providing relevant information that could assist users to identify and classify particular types of EBFs. "Nonmarket nonprofit institutions that are both controlled and mainly financed by government units are legally nongovernment entities, but they are considered to be carrying out government policies and effectively are part of government. Governments may choose to use nonprofit institutions rather than government agencies to carry out certain government policies because nonprofit institutions may be seen as detached, objective, and not subject to political pressures. For example, research and development and the setting and maintenance of standards in fields such as health, safety, the environment, and education are areas in which nonprofit institutions may be more effective than government agencies" (paragraph 2.29).

Similarly, the GFSM appears to acknowledge that social security funds will sometimes (or even normally) take an extrabudgetary form since such funds must satisfy the general requirements of an institutional unit, namely "be separately organized from the other activities of government units, hold its assets and liabilities separately, and engage in financial transactions on its own account" (paragraph 2.21).

While GFSM 2001 can help identify the economic status of EBFs and their affiliation to the government or the broader public sector, a more detailed typology might be useful for detailed fiscal analysis and presentation. To this end, EBFs can be grouped according to their: (i) objectives; (ii) sources of funds; and (iii) institutional design. Many EBFs combine items from more than one of the below categories. 


\section{Objectives}

- $\quad$ Special funds: funds established for specified purposes and financed from special taxes or other earmarked revenues required usually by law, such as social security funds, health funds, and road funds.

- Development funds: funds established to support development programs usually involving donor contributions and sometimes internal sources (e.g., privatization receipts), such as social funds, environmental funds, and sectoral funds.

- Contingent (reserve) funds: funds held for emergencies or unexpected expenditures.

- Stabilization funds: funds established to reduce the impact of volatile revenue on the government and the economy, such as oil stabilization funds.

- Savings funds: funds that seek to create a store of wealth for future generations, such as oil savings funds.

- $\quad$ Financing funds: funds used to finance the overall budget balance, and not regular expenditures, most often by utilizing oil and other nonrenewable resource revenues, such as oil financing funds.

- Counterpart funds: funds linked to inflows of donor aid (including in-kind) and managed under specific procedures, taking into account the requirements of the donors concerned.

- $\quad$ Revolving funds: funds that are replenished, usually through charges made for goods and services and on-lending operations, and whose income remains available to finance its continuing operations, which would otherwise be jeopardized by budget rules that require budgetary appropriations to expire at the end of the year.

- $\quad$ Trading funds: funds established to provide a financial mechanism for government trading activities on the principle of self-financing.

- $\quad$ Sinking funds: funds accumulated by a government or governmental body, usually arising from taxes, imposts or duties for the purpose of repaying a debt.

- Miscellaneous extrabudgetary accounts, including secret funds: held by government ministries and agencies, frequently for the hypothecated use of ministers and nominated officials.

\section{Sources of finance}

- $\quad$ Earmarked revenues: both general (e.g., defined as a percent of total revenues) and specific (identified with a specific tax or social security contributions).

\section{- Transfers from the budget.}




\section{- User charges.}

- Sales of financial and nonfinancial assets, including privatization receipts: usually use for one-off purposes.

- $\quad$ Sales of goods and/or services.

\section{- Borrowing.}

- Donor funds: including direct aid contributions and/or debt relief, and debt swap arrangements.

\section{Institutional design}

- Funds managed centrally by the ministry of finance or the treasury: the motivation for establishing such funds is, most often, to avoid the restrictions of the budget process, as, for example, in the case of centrally managed revolving funds.

- $\quad$ Funds managed by line ministries and/or other spending agencies: in addition to the motivation above, these funds may be established to avoid expenditure controls applied to budget organizations.

\section{- $\quad$ Funds managed by autonomous agencies.}

Many of the above activities or funds can also be organized as on-budget funds. In these cases, they are part of the budget but are earmarked for special policies and purposes. For example, all trust funds in the United States are on-budget, except the two social security retirement trust funds, which are classified as EBFs.

\section{WhY Do EBFs EXIST?}

The existence of EBFs can be considered from different viewpoints. This paper argues that in many or most cases, extrabudgetary transactions or entities exist or are established because of the combination of two main groups of factors: a series of "market" or budget system failures and political economy factors. However, there are other specific economic arguments, extensively considered in the literature, that could be appropriately linked to the discussion of EBFs. These include the benefit principle of taxation and the principle of earmarked taxes. Some governance considerations, mainly related to the agency model applied in a number of OECD countries, are also increasingly relevant to the existence of EBFs.

\section{A. Budget System Failures}

The budget system failures may be divided into the following categories:

- Mismatch of time horizons. Certain categories of EBFs - relating to social security funds, oil stabilization funds, and oil savings funds, for example - are established to provide income for pensioners or future generations, or to provide security against a 
change in economic circumstances, such as the decline in natural resources, in the long term. However, the time horizon for such funds is much longer than that for the traditional budget, which may only be one year or, at the maximum, three to five years.

- Interference of special interests with the budgetary process. The misallocation of resources that results from such manipulation of the budget process - too little funding for road maintenance, too much for "pork barrel" projects - often leads to the creation of EBFs that are designed to secure some measure of insulation from these practices. The basic motivation is to provide security with a hypothecated source of funding as a way of preventing too many or too few resources being allocated.

- Inadequate mechanisms for allocating resources. Examples include the "capture" element in the budget (civil servants setting preferences rather than these being established through the political process); conflicts that arise between the executive branch and the legislature in setting priorities and making choices between competing claims on resources; and the absence of a mechanism for reconciling the needs of the purchasers and providers of public goods and services.

- $\quad$ Failure to recognize the needs of local communities in allocating resources. Budget systems in some countries are concentrated in central agencies such as the finance ministry and the treasury with only weak mechanisms for transmitting information about economic conditions and budget priorities from the periphery to the center, and little responsiveness to local needs. In such an environment, there is an incentive for local authorities and communities to establish alternative mechanisms for meeting the budgetary requirements that are unsatisfied through the normal channels, including through EBFs.

- Ineffective control and incentive mechanisms for public sector managers, especially in large ministries and other organizations that may have overlapping and sometimes conflicting policies and operational goals. Many OECD countries consider the agency model as an appropriate alternative to traditional budget organization, in order to introduce or strengthen such mechanisms. Although agencies can operate within the budget system, in many cases they are organized as EBFs, which, among other things, allows them to retain and use fees and charges to finance their own expenditures, rather than transferring these revenues to the budget.

- Unsatisfactory governance arrangements for accountability and transparency. In particular, mechanisms for the external oversight of the budget in developing countries are frequently undeveloped. In many such countries, no independent external audit body exists, or its role and responsibilities are severely limited de jure or de facto. Similarly, the oversight powers of the legislature are frequently limited by the absence of sufficient statutory authority and resources to exercise its role effectively. Under these conditions, EBFs can be established and flourish without challenge from the oversight bodies. 
- Ineffective mechanisms for addressing donors' fiduciary requirements. Though budget support is becoming increasingly important as a way of providing aid and promoting the reform of public financial managment, especially in the context of the February 2005 Paris Declaration on Aid Effectiveness, ${ }^{6}$ it still represents a relatively small portion of foreign aid. A recent IMF study indicates that budget support has risen from about 10 percent of total aid commitments in 2000 to 20 percent in 2005 . $^{7}$ In practice, many donors still use traditional funding methods that effectively ringfence the aid funds, ostensibly to reduce fiduciary risk.

A comprehensive policy framework for analyzing EBFs, and recommending measures to deal with them, needs to take account of the factors above, as well as the more immediate macrofiscal problems to which EBFs may give rise.

\section{B. Political Economy Factors}

A case for establishing EBFs is frequently put forward on political economy grounds. Indeed, this is often a dominant factor, as the following examples demonstrate.

- To protect politically sensitive programs from budget cuts or other short-term considerations in the context of the annual budget cycle. The ongoing discussions on the social security reform process in the United States represent a good example. The 1983 National Commission on Social Security Reform (the Greenspan Commission) argued that "changes in the social security program should be made only for programmatic reasons, and not for purposes of balancing the budget." This, according to the majority of the members of the commission, "would be more likely to be carried out if the social security program were not in the unified budget.",

- To give an appearance of a smaller budget deficit, by financing certain programs outside of the budget through EBFs, even though the government still needs to finance this spending.

- To generate political support for introducing new taxes. For example, the establishment of a health fund, and the introduction of a health tax to finance its expenditures, could be more acceptable politically than the increase in revenues required to finance the general government expenditures, although the macrofiscal

\footnotetext{
${ }^{6}$ The Paris Declaration was issued jointly by the World Bank, the Asian Development Bank, the European Commission, the United Nations, the Development Committee of the OECD, and partner countries, and followed similar Declarations at Monterrey (May 2002) and Rome (February 2003). Among other elements, the Paris Declaration stated that the partners should "use country systems and procedures for planning, disbursement, procurement, monitoring, reporting, and auditing [of aid]." Indicators were established to monitor progress on this and other elements of the Declaration.

${ }^{7}$ See Gupta, Pattillo, and Wagh (2006).

${ }^{8}$ Eventually the U.S. Social Security Fund was organized as an off-budget program and included in the unified budget (see Box 5).
} 
effect is equivalent. Similarly, the establishment of an environmental fund can facilitate the introduction of an environmental tax.

- To recognize and mobilize a social consensus that certain important activities are underfunded in the annual budget. The establishment of a dedicated road fund or an environmental fund is often considered a political act of recognition of the importance of these activities that is also appealing to broad social groups, although in practice this would not necessarily improve the financing of these activities.

- $\quad$ To insulate donors' projects and programs in priority sectors at their request. Although the economic rationale for channeling donors' aid through EBFs is generally weak, their use in specific cases may be justified on political grounds. For example, following the change of government in the West Bank and Gaza in 2006, the donor community has considered alternative options to provide financial assistance to the Palestinian people, including through extrabudgetary trust funds under the president's control, in order to insulate the government from managing foreign aid.

- To protect funds from public scrutiny, contrary to generally accepted principles of transparency. For example, the government of Estonia set up a privatization fund in the 1990s which made earmarked privatization receipts less evident to politicians and susceptible to spending pressures. The Kuwaiti Reserve Fund for Future Generations is prohibited by law from disclosing its assets and investment strategy. The authorities justify this policy on the grounds that if the public knew the true extent of official assets, there would be greater pressures to spend. Similarly, in Indonesia, fiscal surpluses were hidden from public view in the 1970s and 1980s, which arguably sowed the seeds of subsequent governance problems and political turbulence.

Certainly, it is difficult to reconcile some of the arguments and cases summarized above with the well-established principles of good governance and sound financial management. Moreover, there may be cases where opposite motives are used to justify the establishment or existence of an EBF. For example, if a petroleum fund is established, the authorities may claim that the purpose of the fund is to enhance transparency, but the real objective, or real impact, may be to conceal its operations from public scrutiny. When analyzing a specific case, it is important to clarify the motivation underlying the government's presentation of the arguments.

\section{Benefit Principle of Taxation and Earmarking}

The establishment of EBFs under certain circumstances can be considered in the context of two related principles: the benefit principle of taxation, and, since many EBFs are financed from a specific stream of tax revenues, the principle of earmarked taxes. ${ }^{9}$ Related to these are the arguments that have also been put forward on the basis of Buchanan's theory of public

\footnotetext{
${ }^{9}$ See Musgrave (1959).
} 
choice which argues that a consolidated budget is not necessarily an efficient mechanism for allocating resources ${ }^{10}$ (see Box 2).

The benefit rationale relates to fiscal earmarking through assigning revenues from designated sources to finance designated expenditures. Fiscal earmarking is a typical feature of most important EBFs, although in many cases earmarked revenues are used to finance entities or transactions that are part of the budget. Social security funds, and, to some extent, public health funds, are considered the clearest example of EBFs to which the benefit principle of earmarking is applied, using the argument that the premiums (contributions) are paid by the social partners (employers and employed) and that the funds thus "belong to" these groups at least to the same degree as to the government. For the same reason, the social partners are often represented on the board of management of such funds, ${ }^{11}$ and generally there are

\section{Box 2. Benefit Principle of Taxation and Fiscal Earmarking}

The benefit principle, which dates to the $17^{\text {th }}$ century, holds that people should pay taxes according to the benefits they receive from government programs. Under this view, taxing according to the benefits received may be seen as a way of confronting taxpayers with the true cost of government goods and services. It is hoped that this will lead taxpayers to make better-informed decisions about the size and scope of government. However, this argument has limitations since it is very hard to measure accurately the benefits that individuals receive from a wide range of government services. Moreover, public goods provided through the budget (e.g., national defense) are indivisible and raise the "free rider" problem, namely that no-one can be excluded from the benefits to which the expenditures give rise. In addition, taxes are compulsory and the benefit principle does not account for the taxpayer's ability to pay, another yardstick against which the fairness of a tax is measured.

Earmarking refers to the practice of dedicating a specific stream of revenues to a specific expenditure purpose. The most common example is the dedication of highway revenues (gasoline taxes, motor vehicle registration fees) to the construction and maintenance of streets and highways. Sometimes this process is managed through an $\mathrm{EBF}$, such as a road maintenance fund.

Generally, public finance and public administration experts disapprove of earmarking on the grounds that it rigidifies the general budget, depriving elected officials of the freedom to allocated funds among competing expenditure programs in accordance with currently perceived needs. It causes some parts of the budget to be over funded relative to what elected representatives would otherwise have appropriated, and other parts to be under funded. Earmarking is also criticized for removing part of the public budget from the same legislative scrutiny and oversight given to other budget expenditures.

Earmarking, however, has also been defended as a strategy for "unbundling" items in the budget. If expenditures were financed through a system in which citizens voted directly on a series of tax/expenditure issues, the "package deal" approach that characterizes the annual process of budget negotiation in many countries could be avoided. Voters would be given a wider scope for public choice, and the resulting budget allocations would, arguably, more accurately reflect citizen preferences.

Source: Cordes, Ebel, and Gravelle (2005).

\footnotetext{
${ }^{10}$ See Buchanan (1963).

${ }^{11}$ See Kraan (2004).
} 
separate laws for the management of these funds and their budget procedures. In some countries, for example the United Kingdom, this theory has become redundant since the social security funds, once independent, have become fully integrated with the budget, and are financed on a pay-as-you-go basis by social security contributions. These contributions, while retaining their title, have thus become de facto part of government revenues. Nevertheless, except perhaps in the case of social security funds, earmarking is not a clinching argument for EBFs since similar political economy benefits can be achieved through the budget process.

\section{The Agency Model}

The agency model for managing public funds is sometimes advanced as a justification for EBFs since many agencies are set up on an extrabudgetary basis. ${ }^{12}$ A definition of public agencies is presented in Box 3. The agency model is most commonly found in developed countries, where it has reached an advanced form, but also in some transition and developing countries. Provided they are appropriately structured and supported by a well developed institutional framework, agencies bring potential microeconomic efficiency gains when they act as a purchaser not a provider of services (i.e., have the freedom to focus on improving service delivery and achieving greater efficiency). While technically agencies do not have to be constituted as EBFs, it has been argued that the potential benefits they bring are most likely to be realized when they are given significant financial independence, and this may be difficult if they are tied directly to the budget process. However, a detailed analysis of the advantages and disadvantages of the agency model is beyond the scope of the present paper. ${ }^{13}$

\section{Box 3. Definition of Public Agencies}

For working purposes, an agency can be defined as a body that:

- $\quad$ operates with some degree of autonomy from political direction;

- $\quad$ is established in a founding law, charter or contract;

- $\quad$ manages its budget autonomously, but within a framework of rules set by the government;

- $\quad$ is financed through a combination of own source revenues, earmarked contributions and transfers from the state budget;

- $\quad$ has assets that are owned by the public and may not be used for private benefit; and

- $\quad$ is accountable to the public, as defined by law and tradition.

Some of these features, especially items 3, 4 and 5, are also defining characteristics of EBFs.

\footnotetext{
${ }^{12}$ This is consistent with the approach under GFSM 2001, in which, as explained in Section II, many agencies are classified as extrabudgetary entities.

${ }^{13}$ For a good overview of the theory and practice of the agency model, see OECD (2002).
} 
When established as public agencies and accompanied by either administrative mechanisms or market-like incentives that promote accountability and efficiency, EBFs can lead to microeconomic efficiency gains by simulating private market conditions where levels and standards of service are linked directly to fees and charges. They can also provide a more consistent source of funding for expenditures that yield high benefits yet do not get much recognition in the budget preparation process (maintenance expenditures for capital infrastructure being a primary example).

However, the freedom of action to take decisions about both operational management and the planning and use of resources, which is the hallmark of agencies, may open the door to a new set of risks if the governance and public financial management arrangements for these bodies are poorly designed. Such risks may include the following: public money and public assets being used for purposes not intended by government and parliament; public borrowing increased beyond approved limits; new opportunities for corruption being created; citizens rights compromised without proper redress; and accountability arrangements such as transparency, financial reporting and audit being neglected. In addition, if there are insufficient trained people or inadequate information systems, it will be impossible to implement high quality controls; and if the central bodies of an administration themselves do not have effective budgeting and control practices there is little hope of enforcing higher standards for subordinated agencies. The challenge facing government authorities is thus to build an architecture of financial management and control to ensure that the advantages of agencies can be achieved without threatening fiscal discipline and allocative efficiency.

A recent paper by OECD/SIGMA recommends that countries should establish a comprehensive framework for the governance and financial management of their public agencies. ${ }^{14}$ This framework should cover areas such as: the control and management of real property assets; borrowing; revenue raising policies; earmarked contributions; budget formulation and budget approval; oversight of staffing and personnel costs; budget execution and control; performance management; accounting, and reporting.

Many OECD countries have made substantial progress in developing such a framework - a good example is the regime for managing nondepartmental public bodies, formerly known as "quangos," in the United Kingdom (see Box 4). However, the progress made in most transition and developing countries has been generally less successful, reflecting in part weaknesses in their systems of public financial management. Even in advanced countries, however, the development of appropriate financial management rules for public agencies is a difficult and complex process, in which there is an inherent tension between the role of the ministry of finance, whose goal is to enforce rigorous standards of financial management, and the "parent" line ministries, who tend to advocate looser standards of control and the exercise of considerable discretion by agencies in the use and management of their resources.

\footnotetext{
${ }^{14}$ SIGMA (2001). The paper sets out general principles and recommendations based on an analysis of the experience of agencies in five EU countries: France, the Netherlands, Portugal, Sweden, and the United Kingdom.
} 


\section{Box 4. A Governance and Financial Regime for Nondepartmental Public Bodies}

According to the UK Cabinet Office, a nondepartmental public body "has a role in the process of national government, but is not a government department (i.e., ministry) or part of one and which accordingly operates to a greater or lesser extent at arms' length from ministers." Nondepartmental public bodies operate under a financial regime that allows them to operate their own budgets but subject to common standards established by the finance ministry (HM Treasury). ${ }^{1}$ Another class of agency in the United Kingdom, the so-called "Next Steps Agencies" remain integral parts of the ministry but have substantial flexibility in budget and personnel management and separate accounting and reporting arrangements. A notable feature of the United Kingdom system is "the existence of an over-arching complex of standards that apply to .... entities within the public sector, including those with separate legal personality. The system includes rules issued by HM Treasury for accounting, reporting, audit, etc. and a Standing Committee on Standards in Public Life which promulgates governance standards and codes of conduct for board members and officers. In addition, agencies in all classes are subject to audit by the National Audit Office." 2

1/ UK Cabinet Office (2004). See especially Paper No. (i) Financial Management—Planning, Funding and Control. The control arrangements include an intriguing and subtle use of incentives. For example, a nondepartmental public body spending scores against the budget appropriation of the "parent" ministry. Thus departments "must ensure that they are able to control the expenditure of their NDPBs in order to stay within their limits."

2/ SIGMA (2001).

\section{The Problems Created by EBFs}

The IMF has generally considered EBFs problematic as undermining the soundness of fiscal policy, fiscal discipline, flexibility, and transparency. The associated problems have traditionally been assessed in two main contexts - fiscal policy analysis and public financial management. Such problems, however, are not necessarily endemic to EBFs as a category of public institution, and may normally be attributed to poorly designed financial management and governance procedures.

The fiscal policy considerations mainly relate to the soundness of fiscal analysis and fiscal policy formulation. The lack of full and timely information on the activities of EBFs, as a result of their insulation from the regular budget process, can significantly distort the assessment of the overall macroeconomic and fiscal position, including with respect to critical dimensions such as: the size of the general government; its contribution to aggregate demand, investment, and saving; the tax burden; and the social safety net.

In addition, the possibility for EBFs to borrow, as in the case of some social security funds, or to implement quasi-fiscal or on-lending operations, as in the case of some revolving and trading funds, may have a significant impact on the sustainability and transparency of fiscal policies, and contingent claims against the government.

The consequences for heavily-indebted poor countries can be especially serious because EBFs may have a sizable effect on their debt position and on the effectiveness of spending related to poverty alleviation. In the wake of the multilateral debt relief initiative, an immediate issue is the need for a comprehensive debt management strategy in the countries concerned. 
The empirical evidence suggests that, in many cases, EBFs do not achieve their intended policy goals. For example:

- $\quad$ The IMF paper on stabilization and savings funds for nonrenewable resources concludes that saving performance in oil producing countries did not seem to be affected by the existence or otherwise of an oil fund. ${ }^{15}$

- According to a preliminary appraisal of the second generation of road funds in Africa, conducted by the World Bank, although funding for maintenance has increased in the countries that have established such funds, the amounts still fall short of what is needed: "In contrast, Uganda, which has not created a road fund, has consistently met most of its maintenance budget requirements as well as counterpart funding needs through the normal budget process. It has committed more resources for maintenance per kilometer of road than any of its "securely funded" neighbors. It has also made explicit commitments to sustain maintenance funding, as well as salaries and employment conditions offered by executing agencies, after the main donor financing ends." $" 16$

Extrabudgetary funds should also be assessed against the three key levels of good public financial management: fiscal discipline (overall expenditure control); the allocation of resources consistent with policy priorities (strategic allocation of resources); and good operational and cash management of expenditure (economy, efficiency, and effectiveness). In this context, the IMF's Guidelines for Public Expenditure Management ${ }^{17}$ summarizes the potential drawbacks of the EBFs as follows: "EBFs can result in a loss of aggregate expenditure control, because such expenditure may be outside the control of the ministry of finance; EBFs can distort the allocation of resourses by circumventing the budget process and review of priorities; earmarked revenues can become entrenched so funding is no longer based on priority needs; less transparency may lead to inefficiency and/or misuse of funds; EBFs can facilitate rent-seeking and abuse of monopoly power; and EBFs are incompatible with good cash management practices." Such problems, however, may often be mitigated by appropriate features in the design of EBFs, and establishing a strong interface between these bodies and the budget process.

Extrabudgetary funds are also sometimes associated with the dilution of accountability and control, problems in reporting and consolidating fiscal data, the diversion of limited administrative capacity, and restrictions on modifying taxes that are earmarked for financing EBFs. Moreover, some analysts consider EBFs a good example of an area where political and administrative corruption are entwined. ${ }^{18}$ In this context, they refer to cases where "little

\footnotetext{
${ }^{15}$ See Davis and others (2001).

${ }^{16}$ Gwilliam and Kumar (2003, pp. 113-28).

${ }^{17}$ Potter and Diamond (1999, p. 26).

${ }^{18}$ Allen and Tommasi (2001).
} 
empires" have been built with public resources through the use of EBFs, and where political parties are financed through these funds.

Even if the benefit principle of taxation or budget system failures, as discussed in the previous section, might justify some EBFs, these may still introduce distortions in the allocation of resources both across and within sectors. For example, it has been argued that road funds in India have drained investment resources into the road sector at the expense of other transport sectors, especially railways. As a result, the overall development of the transport sector has been distorted at a higher cost to the economy and with a negative impact on the environment.

Extrabudgetary funds frequently maintain their own banking arrangements. In addition to EBF borrowing, these separate arrangements are often at the heart of fiscal control and governance problems. In Lithuania, for example, the social insurance fund borrowed at a sizable premium over the official rates and often took expensive, short-term bridge loans, even though there was a strong, implicit government guarantee. The arrangement was terminated with significant savings in interest payments.

One major risk from EBFs is their tendency to proliferate into hundreds or thousands of individual units, thus atomizing political governance and fragmenting and undermining the overall quality of public financial management. The very existence of "good" EBFs is a source of invidious comparisons and a justification for setting up funds that have no strong basis and are poorly managed and controlled. In a country with few and less diverse EBFs, and an otherwise well-run budget system, the fiscal problems associated with EBFs may be manageable. This is unlikely to be the case, however, if there is a proliferation of EBFs and dozens or even hundreds of entities run by a wide range of ministries and agencies. While individual EBFs may even be considered relatively benign, their aggregate impact on fiscal flexibility and the quality of fiscal management might be very serious. Country experience confirms this conclusion. The significant number of EBFs in many central and eastern European countries in the early 1990s, including in Russia, Poland, and Bulgaria, as well as in Turkey, had a damaging impact on their overall fiscal performance. The current proliferation of extrabudgetary activities through the formation of public law entities and noncommercial organizations poses similar fiscal risks in countries such as Georgia and Armenia. Ghana is another example of a country with a plethora of statutory funds in sectors such as roads, social security and mining, that have had an adverse impact on overall budget management.

Specific public financial management problems stem from the use of EBFs in managing donor aid funds. Despite the increased role of budget support in providing donor aid, as indicated above, extrabudgetary transactions are still widely used in managing donor contributions. Many donors feel comfortable with such arrangements because they are accountable to their own taxpayers and in their view EBFs are likely to be better managed than the general budget and can yield better results and outputs. However, from a strategic point of view, such an approach may have a negative impact on the development of a national public financial management system. The creation of "islands of excellence" rarely leads to a general improvement in management capacity, and indeed may serve to erode effectiveness elsewhere in the system, for example by diverting scarce skilled staff from civil 
service positions and distorting wage structures. In Yemen, for example, staff who run the Social Fund for Development (90 percent of whose funds come from donors) are paid 6-10 times the government pay scales.

\section{CRIteria FOR EVAluAting AND ReForming EBFs}

On the basis of the previous analysis, this section proposes a series of criteria which governments might use to evaluate whether their EBFs should continue to exist, be changed in form through commercialization or privatization, or be abolished.

First, there should be a satisfactory economic and governance case for establishing EBFs. The issues discussed in Section III are particularly relevant:

Under the benefit principle, earmarked taxes are seen as serving a purpose similar to that of prices in private transactions; that is, they help determine what activities the government undertakes as well as who pays for them. This link is most clear in the case of social security funds financed by earmarked taxes or contributions that justifies their existence and recognition as the main form of extrabudgetary activity in many developed and developing countries, but is also relevant to other cases such as road funds and environmental funds that are financed from user charges.

The governance rationale stresses the importance of strengthening administrative mechanisms and market-like incentives to promote accountability and efficiency. One common approach is the introduction of an agency model for managing public funds which, in many cases, are not included in the budget. Potter ${ }^{19}$ has suggested some important requirements for setting up efficient road funds under an agency model that could be applied to EBFs that are financed through earmarked revenues or user charges, including that:

- $\quad$ The fund should be dedicated 100 percent to the task in question - and not simply used as a means of avoiding budget discipline.

- $\quad$ The fund should be constituted as an agency and operate principally as a purchaser, not as a provider of services. Thus it should have, as a minimum, a mission statement, clearly documented goals and objectives, physical and financial output indicators, and a total resource envelope.

- $\quad$ Arrangements should be in place to ensure the efficient management of the EBF's total resource envelope, and associated accounting, control and financial reporting requirements. In addition, the government should ideally have access to the fund's cash balances for cash management purposes.

- A management board with a significant private sector presence but genuinely free of a producer (whether supplier or trade union) interest should be established; the board should operate with independence, objectivity and impartiality.

${ }^{19}$ See Potter (2005). 
Second, EBFs should be properly structured and designed from an economic and governance point of view. The IMF paper on nonrenewable resource funds emphasizes that their design is of critical importance; otherwise, they may well do more harm than good. ${ }^{20}$ The paper identifies the key features of a well-designed fund, including:

- coordination of the fund's operations with those of the rest of the public sector, in the context of a sound fiscal policy;

- $\quad$ effective consolidation with the budget; and

- $\quad$ a mechanism to ensure full transparency and accountability.

These features can be most effectively realized through consolidation of EBFs with the legislative budget. To this end, information on EBFs should be included in the budget documents alongside data on the general budget. A possible model for this is the concept of the unified budget that has been applied in the United States (see Box 5) and many other OECD countries. However, the application of this approach should not be used to obscure the long-term fiscal consequences of social security funds, and certain other EBFs such as oil revenue funds, which require a separate presentation and analysis in budget documents and fiscal reports within the consolidated framework.

\section{Box 5. The U.S. Concept of a Unified Budget}

In the 1967 Report of the President's Commission on Budget Concepts, a comprehensive budget is defined in which receipts and outlays from federal and trust funds are consolidated. When this group of funds is consolidated to display budget totals, transactions that are outlays of one fund for payment to another fund (namely, interfund transactions) are deducted to avoid double counting. The unified budget should, as conceived by the President's Commission, take in the full range of federal activities. By law, budget authority, outlays, and receipts of off-budget programs (currently only the Postal Service and Social Security) are excluded from the current budget, but data relating to off-budget programs are displayed in the budget documents. However, the most prominent total in the budget is the unified total, which is the sum of the on- and off-budget totals.

Source: U.S. General Accountability Office (2005).

Third, the transactions of EBFs should meet basic public financial management requirements. They should be subject to parliamentary scrutiny and meet acceptable standards of accounting and reporting, internal control, internal and external audit, as well as basic transparency requirements. As set out in the IMF's Code of Good Practices on Fiscal Transparency, all extrabudgetary activities of the central government should be presented in the budget documents, final accounts and other fiscal reports, and the consolidated fiscal position of the central government should be published. Contrary to the argument often put forward for establishing such funds in some developing and transition countries, namely to

${ }^{20}$ See Davis and others (2001). 
keep the resources hidden from public view, a motive for establishing funds in some cases is to present a clearer picture of both the underlying budgetary position and the use of these resources.

Fourth, the requirements for establishing and operating EBFs need to be supported by a sound regulatory framework. The use of informal arrangements for organizing extrabudgetary activities often indicates the lack of any public scrutiny, thus permitting illegal activities. In most OECD countries the rules for creation of EBFs are defined in a legal setting, usually through provisions in the budget system law, and more rarely through constitutional provisions or government decrees. ${ }^{21}$ In cases where there are agencies that operate like EBFs, there is a need for legislation that specifies appropriate budgetary, accounting, reporting, and auditing arrangements as well as rules regarding the accountability of EBF management.

Fifth, should an EBF be financed through earmarked revenues, the accountability, transparency, and adequacy of the revenue collection function should also be addressed. Revenue collection can be organized in two fundamental ways: either integrated within the tax collection system - national or local — with funds earmarked for the special purpose, or run as a parallel system by the EBF. The rationale for consolidating government collection responsibilities into one revenue collection organization is strong. Key advantages include:

- $\quad$ use of common core processes such as identification and registration of payers, availability of collection information systems, definitional overlap of income, use of existing payment networks - such as banks, effective follow-up of nonpayers and nonfilers, and verification processes using risk-based audit techniques;

- $\quad$ more efficient use of resources as the core collection capacity is used for multiple purposes;

- recognition of the tax administration's core competence in collection with its compliance-based organizational culture;

- $\quad$ reductions in administration costs because of economies of scale; and

- $\quad$ reductions in the compliance costs on taxpayers that result from the simplification of forms and procedures, less record keeping, and a common audit program. ${ }^{22}$

While there are many benefits to integrating the collection function, a careful assessment must be made of the readiness of the government's tax administration to take on new responsibilities. A weak administration with fragmented responsibilities, ineffective collection and audit functions, poorly trained staff and ineffective management is unlikely to be in a strong position to achieve the desired outcomes. In these cases, reform and

\footnotetext{
${ }^{21}$ OECD/World Bank (2003).

${ }^{22}$ See Barrand, Ross, and Harrison. (2005).
} 
modernization of the tax administration should be undertaken alongside other reforms in the reporting and management of EBFs.

Evaluation of country experience suggests that many EBFs are unlikely to satisfy all the criteria set out above, especially in transition and developing countries in which the basic governance and financial infrastructure is weak. However, there are exceptions to this statement. As noted above, many OECD countries have allowed and even encouraged EBFs to exist alongside a strong regime for their governance and financial management. Some of these countries have undertaken systematic reviews of their EBFs that have abolished or merged many of them, and converted others into commercialized or privatized bodies. Progress along these lines has also been made in some middle-income countries. An interesting example is the transition of Bulgaria from a public financial management system with a proliferation of EBFs, in the early 1990s, to a system that successfully manages the problems associated with a much reduced number of EBFs in line with good practice (see Box 6).

Some analysts have argued that EBFs could be regarded as an interim step toward the commercialization or abolition of the agency concerned: the example of a road fund has been cited, and development funds established by donor agencies is another example, as noted above. ${ }^{23}$ However, this is the reverse of the position advocated in the present paper, namely that, in general, funds should only be established if they are subject to rigorous governance

\section{Box 6. Reforming EBFs in Bulgaria}

\section{Legal framework}

The 1996 Budget System Law introduced the concept of a consolidated budget and provided a broader legal framework for extrabudgetary activities. The consolidated budget includes the budget and the EBFs.

\section{Closure of EBFs}

In 1997-99 all extrabudgetary accounts of budgetary organizations (over 1,200) were closed and the number of EBFs (established to finance national programs) was reduced from over 70 to about 20.

\section{Budget and treasury coverage}

EBFs are included in the annual budget presentation to parliament. They are part of the treasury single account and are required to meet the budget requirements for accounting, internal control, internal and external audit and reporting.

\section{Revenue collection}

The collection of social security and health insurance contributions has been integrated within the tax collection system under a unified revenue agency.

\section{Management of EBFs}

EBFs have substantial managerial autonomy. There are separate laws for the biggest EBFs (the Social Security Fund and the Health Insurance Fund). However, their regulatory framework as well as their business planning and operations should fully comply with the broader legal framework for extrabudgetary activities defined in the Budget System Law.

\section{Fiscal consolidation}

The problems with EBFs were addressed in the context of a broader fiscal consolidation reform. Since 1998 the consolidated budget has been kept broadly balanced.

\footnotetext{
${ }^{23}$ See Schwartz, Corbacho, and Koranchelian (2006). Also Gwilliam and Shalizi (1999).
} 
and financial management arrangements that are unlikely to be found in many transition and developing countries. Where "transitional" funds of this kind exist, even if they perform successfully in relation to their mandate and objectives, the risks of contagion and collateral damage to the national budget system are likely to be high.

\section{Implications for the Analysis of Fiscal Policies and Public Financial MANAGEMENT}

The implications of the criteria set out in Section V are in two main areas: macrofiscal policies, including fiscal analyses and policy recommendations, and public financial management, including diagnostic and technical assistance work.

The main focus in the context of analysis of macrofiscal policies should be on: (i) the proper classification of EBFs in line with GFSM 2001; and (ii) consolidation of data on EBFs in fiscal tables. This needs to be done on a gross basis, including revenue, expenditure and financing items. ${ }^{24}$ The lack of a full coverage of EBFs in the data can distort fiscal and macroeconomic analyses and policy recommendations.

Work on consolidating data on EBFs within the fiscal tables should start with the definition of the general government in line with GFSM 2001. EBFs are part of the general government sector and should be classified in one of its subsectors (central government, state government, or local government) or as a separate subsector. This classification is important because EBFs exist not only in central government but also at the regional government and local government level. In practice, however, the information that is available on EBFs at the subnational level of government is likely to be much less than at the national level.

Subnational governments should be encouraged to improve these reporting arrangements, if possible on a uniform basis with central government.

The above approach has been applied in many cases in surveillance work and IMF-supported programs ${ }^{25}$ but more consistent application of the GFSM 2001 methodology will be needed in the future. In November 2005, the IMF's Executive Board discussed and encouraged the use of the GFSM 2001 statistical framework to strengthen fiscal analysis in the Fund and their gradual implementation by the national authorities. ${ }^{26}$ In this context, the GFSM 2001

\footnotetext{
${ }^{24}$ For the purposes of consolidated presentation, the internal transactions between the budget and EBFs need to be deducted to avoid double counting.

${ }^{25}$ In practice, surveillance and program work faces many challenges in properly classifying all extrabudgetary transactions, especially when they are masked under different organizational forms. There is a gray area of extrabudgetary activities that take various names and forms such as noncommercial organizations, "hybrid" funds and public law entities. In most cases, these activities are not properly classified and covered in the budget process. For example, according to the internal regulations, the noncommercial organizations in Armenia were not initially considered a part of the general government sector, although most of them were publicly-managed schools.

${ }^{26}$ There are two main measures envisaged by staff: (i) pilot studies to include the GFSM 2001 operating statement, integrated balance sheets, and cash statements in Article IV consultation reports; and (ii) a migration strategy that should recognize a three phase approach of presentation (short term), country reporting (medium term), and full implementation of accrual reporting and the associated underlying systems (long term).
} 
methodology should be helpful to countries, among other things, in classifying their public sector institutions, including EBFs, in line with a consistent set of economic assumptions and definitions. However, given that precise definitions of the various categories of institutions have not been spelled out in the manual, and that there are gray areas between the various categories, this is unlikely to be an easy task for the countries concerned. ${ }^{27}$

Entities such as government printing offices, hospitals or universities that are presently included in the accounts of many transition and developing countries as central government activities - sometimes as EBFs, other times as part of the budget - may be confirmed as part of general government or may need to be reclassified as public corporations depending on their economic circumstances, commercial orientation and financing arrangements. ${ }^{28}$ In other cases, the borderline between one government finance statistics category and another is relatively fine, and may require the exercise of judgment as well as technical criteria.

The implications for public financial management, including diagnostic and technical assistance work, are more complex. Countries should be encouraged to undertake a systematic review of their EBFs with a view to identifying those that are essential to retain, for economic or political reasons, those that can be converted into commercialized or privatized entities, and those that should be eliminated. In appropriate cases, sunset provisions could be established to phase out redundant EBFs by a specified date.

Ideally, EBFs should be covered by all central public financial management systems used to manage the general budget: cash planning and management, commitment controls, treasury single account, accounting, reporting, internal control, audit, and external oversight. In cases where a separate system for management and control is required by law, this system should meet the minimum requirements described in the previous section, especially in relation to control and fiscal reporting. However, as noted above, the establishment of duplicate systems of control and fiscal reporting can be very costly and time consuming and can lead to diversion of the limited administrative capacity of developing and many transition countries.

The reform of EBFs should be considered in the context of the overall performance of the public financial management system. In countries where the public financial management system is weak, and the budgetary failures noted in Section III.A are prevalent, the main focus should be on strengthening the fundamentals of the system, including basic issues such as budget classification, accounting, and simple reporting systems. By addressing such weaknesses, inefficiencies, and lack of transparency in public financial management systems,

\footnotetext{
${ }^{27}$ For example, one of the categories is a nonprofit institution that engages in "market" activities, such as a hospital or university that charges fees for its services. However, the GFSM does not state the specific criteria for assessing whether a nonprofit institution is "market" or "nonmarket" (e.g., if its receipts exceed 50 percent of its income). The European System of National Accounts (1995) an equivalent set of fiscal reporting standards for EU Member States, provides more precise criteria on this matter.

${ }^{28}$ The GFSM defines two categories of public corporations: corporations and quasi corporations, the key characteristic of which is "not [their] legal status but rather the characteristics of producing goods and services for the market and being a source of profit or other financial gain to the owners." Quasi-corporations are defined as entities "that are not incorporated or otherwise legally established but which function as if they were corporations."
} 
many of the incentives for politicians and government officials to establish new EBFs are likely to be removed. For example, the introduction of a medium-term budget framework often leads to more consistent and adequate budgetary allocations to priority sectors (targeted by some EBFs), thus removing the pressure on the annual budget deliberations. Similarly, the integration of recurrent and capital budgets may improve budgetary allocations for the maintenance and repair of capital projects, making the case for establishing separate infrastructure funds less convincing. In countries with a poverty reduction strategy paper (PRSP), aligning budget priorities with PRSP also reduces the incentive for establishing certain categories of EBFs. As the budget becomes more aligned with the PRSP, priority sectors are likely to receive more recognition in the budget, and this will reduce the incentive to insulate them through the establishment of EBFs.

Taking the above factors into account, the following technical criteria might be adopted in evaluating the role and impact of EBFs:

- Is there a satisfactory economic, governance and political economy case for establishing the EBF? If so, is it possible to consolidate information from the EBF with fiscal tables for the purposes of budget preparation and macrofiscal analysis?

- Is the EBF properly classified according to the guidelines in GFSM 2001? If so, are the procedures for preparing and executing its budget, and financial reporting, comparable to the government's overall framework for managing budgetary expenditures and revenues?

- In cases where the EBF is financed by earmarked taxes, are the arrangements for collecting these revenues satisfactory and compatible with the overall efficiency of tax policy and tax administration?

- Is the legal basis for the EBF adequate in terms of financial management and reporting?

- Is the governance structure of the EBF (e.g., role, responsibilities and independence of the board, transparency of the decision-making process, etc.) compatible with the objectives of sound financial management?

- Is the EBF's budget presented to the legislature in parallel with the state budget and subject to a similar process of scrutiny? If so, how integrated is the EBF with the fiscal objectives of the government?

- Is the EBF's budget subject to audit by the Supreme Audit Institution according to a comparable process and timetable as the general budget?

\section{Summary AND CONCLUSION}

The focus on extrabudgetary funds is warranted on the grounds of their substantial impact on fiscal policy and governance. The size of EBFs in many countries is significant and, by definition, encompasses transactions that are excluded from the legislative budgets and the budgets of local authorities. 
The IMF has traditionally been critical of EBFs, in particular with respect to their impact on the soundness of fiscal policy analysis and control, fiscal discipline, flexibility and transparency. Though there is a sound economic and political economy rationale for establishing EBFs in some cases (social security funds in the first instance), and examples of successful and well-managed EBFs, the traditional argument remains valid in certain circumstances. In such circumstances, experience suggests that the rationale for EBFs can be better achieved by integrating them into the budget process, and that the establishment of EBFs should continue to be regarded as a second-best approach. Where EBFs continue to exist, governments should be encouraged to apply the criteria for evaluating EBFs described in this paper and to strengthen their governance and financial management arrangements.

Frequently, EBFs are established for dubious political reasons that are contrary to wellestablished principles of good governance and sound budgeting. In addition, however, this paper has argued that EBFs exist because of serious failures in the national budget system that provide a strong incentive to bypass it. The implication of this analysis is that the approach to addressing EBFs should incorporate both an emphasis on their macrofiscal consequences, and seeking to legislate against EBFs - which may still be an appropriate policy response in many circumstances - and a focus on developing a program of measures that should be taken, in the medium to long term, to address the underlying budgetary failures. Without addressing these structural issues, it is unlikely that attempts to abolish existing EBFs, or suppress the creation of new funds, will be fully successful.

A strengthened policy approach toward managing EBFs should include the following elements:

- The consolidation of data on EBFs for the purposes of fiscal analyses and the presentation of information in fiscal reports. To this end, a comprehensive list of EBFs should be prepared and classified in line with the concept of general government set out in the GFSM 2001 framework. This requirement should apply even to EBFs that are independently managed under separate legislative authority. The lack of coverage of the EBFs in fiscal tables can seriously undermine transparency and the soundness of macrofiscal analyses and advice. Advice for fiscal surveillance should also stress the need to identify and address the political economy factors and budgetary failures that lead to the creation of many EBFs.

- With respect to public financial management and the provision of related technical assistance, minimum requirements need to be met. Information on EBFs should be included in the budget documentation; and common requirements should be established for the classification of expenditure and revenue, accounting, internal control, and internal and external audit and reporting, using either the budget system itself or comparable parallel procedures. The authorities should be encouraged to introduce the concept of a consolidated budget through the budget legislation and to ensure adequate coverage of the consolidated budget through the public financial management system. They should also be encouraged to consider using the typology outlined in Section II.C as a framework for collecting data on the main characteristics of their EBFs and reporting this information with the budget documents. 
- $\quad$ The approach to EBFs should distinguish between the need, first, for the central authorities to exercise tight control of the EBFs' budget preparation and execution, and for the financial reporting of EBFs to be timely, transparent and subject to rigorous procedures of oversight and auditing; and second, for the EBFs to be given authority to establish their own internal governance arrangements, as appropriate, and manage their business planning and operations in accordance with decisions taken by their senior managers, subject to being held accountable for their organizational performance and results.

- In addition, strong gate-keeping mechanisms, political as well as technical, should be established to reduce the probability that unjustified EBFs will slip under the radar and eventually damage the integrity of the budgeting system. For example, governments should be encouraged to develop and promulgate an agreed policy position on the minimum requirements for EBFs based upon the criteria discussed in Section V; and to formulate a legal framework for EBFs that encompasses essential principles of sound governance and financial management. Such a framework should cover both EBFs as legal and economic entities, and EBFs as transactions, a wider definition, as noted in Section II. Governments should also be encouraged to carry out a systematic review of their EBFs with a view to reducing the number of funds to the minimum necessary to achieve essential policy objectives.

- $\quad$ Finally, greater emphasis should be given to addressing the specific areas of budgetary failure noted above. These include issues that are already covered in many programs and technical assistance work (e.g., the development of medium-term expenditure frameworks, improving the quality of fiscal data, and strengthening financial management information systems). However, there are other areas that are equally important but less frequently addressed: for example, measures to promote the independence of external audit and strengthen the role of the legislature in the budget process, and to decentralize the budget process to improve accountability. In short, there should be a much stronger emphasis on the governance aspects of reform in addition to fiscal reporting, budget classification, financial control, and other "technical" aspects.

Policy advice provided by the World Bank, the IMF, and others also needs to clearly distinguish between EBFs with a strong economic and governance rationale and those that are created to reduce transparency, bypass public scrutiny and hamper fiscal discipline. While the agency model — sometimes on-budget, other times off-budget — has been developed successfully in some OECD countries to encourage a better allocation of public resources, this is not recommended practice for developing and transition countries that do not have sufficiently strong governance and financial management systems to sustain such an approach. Issues relating to EBFs should always be addressed in the context of broader budget and governance reforms, and how these contribute to an overall sound fiscal policy. 


\section{References}

Allen, R. and Daniel Tommasi, 2001, Managing Public Expenditure: A Reference Book for Transition Countries (Paris: Organization for Economic Cooperation and Development).

Barrand, P., Stanford Ross, and Graham Harrison, 2005, “Integrating a Unified Revenue Administration for Tax and Social Contribution Collections: Experiences of Central and Eastern European Countries," IMF Working Paper No.04/237 (Washington: International Monetary Fund).

Buchanan, James M., 1963, “The Economics of Earmarked Taxes,” Journal of Political Economy, Vol. 71, No. 5, pp. 457-69.

Cordes, Joseph, Robert D. Ebel, and Jane D. Gravelle, 2005, The Encyclopedia of Taxation and Tax Policy, (Washington: The Urban Institute Press).

Davis, Jeffrey M., Rolando Ossowski, James Daniel, and Steven Barnett, 2001, "Stabilization and Savings Funds for Nonrenewable Resources," Occasional Paper No. 205 (Washington: International Monetary Fund).

Gupta, Sanjeev, Catherine Pattillo, and Smita Wagh, 2006, “Are Donor Countries Giving More or Less Aid,” IMF Working Paper No.106/01 (Washington: International Monetary Fund).

Gwilliam, Ken, and Ajay Kumar, 2003, "How Effective are Second-generation Road Funds? A Preliminary Appraisal," The World Bank Research Observer, Vol. 18, No. 1, pp. 113-28.

Gwilliam, Ken, and Zmarak Shalizi, 1999, "Road Funds, User Charges and Taxes,” World Bank Research Observer (International), Vol. 14, No. 2: pp. 159-85.

Kraan, Dirk-Jan, 2004, "Best Practices Guidelines-Off-Budget and Tax Expenditures," OECD Journal on Budgeting, Vol. 4, No. 1.

International Monetary Fund, 2001, Government Finance Statistics Manual 2001 (GFSM 2001) (Washington:International Monetary Fund). ,2001, "Observance of Standards and Codes," Manual on Fiscal Transparency, (Washington: International Monetary Fund).

Joint Progress Towards Enhanced Aid Effectiveness Committee, 2005, "Paris Declaration on Aid Effectiveness: Ownership, Harmonisation, Alignment, Results and Mutual Accountability," (Paris: OECD). 
Musgrave, Richard A., 1959, The Theory of Public Finance; A Study in Public Economy, (New York: McGraw-Hill).

Organization for Economic Cooperation and Development, 2002, Distributed Public Governance: Agencies, Authorities and Other Government Bodies (Paris: OECD).

, and World Bank, 2003, OECD/ WB Budget Practices and Procedures Survey, Public Governance and Territorial Directorate Public Management Committee (Paris: OECD).

Potter, Barry H., 1997, Dedicated Road Funds: A Preliminary View on a World Bank Initiative (Washington: International Monetary Fund). ,2005, “Budgeting for Road Maintenance," Round Table 135: Transport Infrastructure Charges and Capacity Choice, European Conference of Ministers of Transport" (Washington: OECD). , and Jack Diamond, 1999, Guidelines for Public Expenditure Management, (Washington: International Monetary Fund).

Schwartz, Gerd, Ana Corbacho, and Taline Koranchelian, 2006, "Financing Transportation Infrastructure-Potential Fiscal Risks and Innovative Financing Mechanisms" (unpublished; Washington: International Monetary Fund).

Support for Improvement in Governance and Management (SIGMA), 2001, "The Financial Management and Control of Public Agencies," SIGMA Papers No. 32 (Paris: SIGMA-OECD).

United Kingdom Cabinet Office, 2004, "Financial Management_Planning, Funding and Control," Agencies and Public Bodies Team, Non-Departmental Public Bodies: A Guide for Departments, (London: UK Cabinet Office).

U.S Government Accountability Office, 2005, “A Glossary of Terms Used in the Federal Budget Process" (Washington: GAO). 